[Case Report]

\title{
A Case of Infectious Enterocolitis with Hyperammonemia
}

\author{
Ken Otsuji ${ }^{1,2 *}$, Satoko Simizu ${ }^{1}$, Takeru Endo ${ }^{1}$, Ayako Kanazawa ${ }^{1}$, Hideaki Arai ${ }^{1}$, Keiji NaGata ${ }^{1}$, \\ Nobuya Harayama ${ }^{1}$, Shunichi Nihei ${ }^{1}$, Keiji Aibara ${ }^{1}$, Mitsumasa $\mathrm{SAItO}^{2}$ and Masayuki Kamochi ${ }^{1}$ \\ ${ }^{1}$ Intensive Care Unit, Hospital of University of Occupational and Environmental Health, Japan. Yahatanishi-ku, \\ Kitakyushu 807-8555, Japan \\ 2 Department of Microbiology, School of Medicine, University of Occupational and Environmental Health, Japan. \\ Yahatanishi-ku, Kitakyushu 807-8555, Japan
}

\begin{abstract}
Case reports of hyperammonemia due to urease-producing bacteria are found occasionally, but most of them are associated with urinary tract infections. We experienced a case of infectious enterocolitis with hyperammonemia in which the causative bacteria was speculated to be urease-producing bacteria. A Japanese woman in her 70s had been diagnosed with microscopic polyangiitis in a nearby hospital and was transferred to our hospital. Although the microscopic polyangiitis was relatively under control after treatment with steroids and rituximab, frequent diarrhea with hyperammonemia $(324 \mu \mathrm{g} / \mathrm{d} l)$ appeared and she became comatose. Her blood ammonia decreased to 47 $\mu \mathrm{g} / \mathrm{d} l$ and her consciousness recovered to a normal state after antibiotic treatment for infectious enterocolitis and ammonia detoxification therapy. Liver dysfunction, portosystemic shunt, excessive protein intake and constipation were not observed, and she took no medications that would cause hyperammonemia. Although culture results could not identify urease-producing bacteria, considering the clinical course, acute hyperammonemia was suspected to be due to urease-producing bacteria infection. It is necessary to consider the influence of urease-producing bacteria as a cause of acute hyperammonemia not only in urinary tract infections but also in infective enterocolitis.
\end{abstract}

Keywords : hyperammonemia, urease, infectious enterocolitis.

(Received June 29, 2017, accepted November 13, 2017)

\section{Introduction}

Hyperammonemia often leads to disturbance of consciousness. Most of the causes of hyperammonemia are liver dysfunction. The influence of urease-producing bacteria is also one of the causes of hyperammonemia, but it is not frequent. There have been reports of hyperammonemia caused by urease-producing bacteria in urinary tract infections and empyema [1-5], but there are no reports of infectious enterocolitis. Here we report a case of infectious enterocolitis with hy- perammonemia in which the causative bacterium was speculated to be urease-producing bacteria.

\section{Case}

A Japanese woman in her 70s was under medication for rheumatoid arthritis and atypical mycobacterial infection in a nearby hospital. She had a past history of surgery for osteoarthritis of the knee joint (49 years old) and right breast cancer (60 years old). She was admitted to a nearby general hospital with a fever and

*Corresponding Author: Ken Otsus, MD, Intensive Care Unit, Hospital of University of Occupational and Environmental Health, Japan. 1-1 Iseigaoka, Yahatanishi-ku, Kitakyushu 807-8555, Japan, Phone: +81-93-603-1611, Fax: +81-93-691-9334, Email: otsujiken@clnc.uoeh-u.ac.jp 
malaise one day in winter. Her laboratory data showed acute renal failure and positive myeloperoxidase antineutrophil cytoplasmic antibody (MPO-ANCA), so she was diagnosed with microscopic polyangiitis. She was transferred to our hospital, and treatment with steroid therapy and rituximab was started. Although her microscopic polyangiitis was fairly well under control, frequent diarrhea was observed and inflammatory response increased from the 16th day of hospitalization. There was no improvement in her condition in spite of intravenous treatment of ceftriaxone, and on the 22nd day of hospitalization the patient became comatose. Her blood $\mathrm{NH}_{3}$ concentration had raised to $324 \mu \mathrm{g} / \mathrm{d} l$ and hemodialysis was performed, but there was no improvement in her consciousness, so she was admitted to the intensive care unit (ICU).

Her body temperature on admission to the ICU was $36.1^{\circ} \mathrm{C}$. Her consciousness level was Eye opening 1 Verbal response 1 Motor response 4 (E1V1M4) in the Glasgow coma scale, her pupil size was $2.5 \mathrm{~mm} / 2.5$ $\mathrm{mm}$ (right/left), and her light reflex was normal. Although her hemodynamic state was stable, her tongue obstructed the airway and her $\mathrm{S}_{\mathrm{p}} \mathrm{O}_{2}$ was $98 \%$ with an oxygen mask with reservoir $\left(\mathrm{O}_{2} 8 \mathrm{l} / \mathrm{min}\right)$. As the patient was comatose, we could not evaluate whether or not she had flapping tremor.

She was medicated with methylprednisolone, ceftriaxone, nifedipine, rabeprazole, azilsartan, sodium bicarbonate, erythromycin, and ramelteon on admission to the ICU.

The laboratory data on admission to the ICU are described in Table 1. Inflammatory response was increased as white blood cells: $30,800 / \mu l$, C reactive protein: $2.71 \mathrm{mg} / \mathrm{d} l$. Although renal dysfunction was observed as blood urea nitrogen: $93 \mathrm{mg} / \mathrm{d} l$, creatinine: $3.95 \mathrm{mg} / \mathrm{d} l$, there was no significant difference from at the time of hospitalization. Despite an increase in blood $\mathrm{NH}_{3}$ concentration to $324 \mu \mathrm{g} / \mathrm{d} l$, her liver function was relatively stable at the prothrombin time-international normalized ratio 1.21 . Hemodialysis was performed before admission to the ICU, and the value of blood $\mathrm{NH}_{3}$ had dropped to $226 \mu \mathrm{g} / \mathrm{d} l$. Coronal section of abdominopelvic plain computed tomography image showed thickening of the ascending colon and ascites around the liver (Fig. 1A). Portosystemic shunts or liver atrophy was not clear. Head computed tomography
Table 1. Laboratory data on admission to the ICU

\begin{tabular}{|c|c|c|c|}
\hline \multicolumn{2}{|c|}{$<$ Blood cell count $>$} & \multicolumn{2}{|c|}{$<$ Blood chemistry $>$} \\
\hline WBC & $30800 / \mu l$ & $\mathrm{TP}$ & $3.9 \mathrm{~g} / \mathrm{d} l$ \\
\hline $\mathrm{RBC}$ & $3.83 \times 10^{6} / \mu l$ & Alb & $1.9 \mathrm{~g} / \mathrm{d} l$ \\
\hline $\mathrm{Hb}$ & $11.0 \mathrm{~g} / \mathrm{d} l$ & T-Bil & $0.6 \mathrm{mg} / \mathrm{d} l$ \\
\hline Het & $31.8 \%$ & AST & $20 \mathrm{IU} / l$ \\
\hline \multirow[t]{2}{*}{ Plt } & $7.4 \times 10^{4} / \mu l$ & ALT & $23 \mathrm{IU} / \mathrm{l}$ \\
\hline & & BUN & $93 \mathrm{mg} / \mathrm{d} l$ \\
\hline \multicolumn{2}{|c|}{$<$ Coagulation system $>$} & Cre & $3.95 \mathrm{mg} / \mathrm{d} l$ \\
\hline PT & $13.2 \mathrm{sec}$ & $\mathrm{Na}$ & $140 \mathrm{mEq} / \mathrm{l}$ \\
\hline PT-INR & 1.21 & $\mathrm{~K}$ & $4.2 \mathrm{mEq} / \mathrm{l}$ \\
\hline APTT & $54.4 \mathrm{sec}$ & $\mathrm{Cl}$ & $104 \mathrm{mEq} / \mathrm{l}$ \\
\hline Fib & $145 \mathrm{mg} / \mathrm{d} l$ & Glu & $171 \mathrm{mg} / \mathrm{d} l$ \\
\hline FDP & $12.0 \mu \mathrm{g} / \mathrm{m} l$ & CRP & $2.71 \mathrm{mg} / \mathrm{d} l$ \\
\hline AT-III & $73 \%$ & PCT & $1.12 \mathrm{ng} / \mathrm{m} l$ \\
\hline \multicolumn{2}{|c|}{$<$ Atrial blood gas $>$} & $\mathrm{NH}_{3}$ & $324 \mu \mathrm{g} / \mathrm{d} l$ \\
\hline $\mathrm{pH}$ & 7.48 & & $\downarrow$ \\
\hline $\mathrm{pO}_{2}$ & $137.9 \mathrm{mmHg}$ & (post HD) & $226 \mu \mathrm{g} / \mathrm{d} l$ \\
\hline $\mathrm{pCO}_{2}$ & $25.4 \mathrm{mmHg}$ & & \\
\hline $\mathrm{HCO}_{3}{ }^{-}$ & $19.1 \mathrm{mmol} / \mathrm{l}$ & & \\
\hline Lac & $2.3 \mathrm{mmol} / \mathrm{l}$ & & \\
\hline
\end{tabular}

WBC: white blood cells, RBC: red blood cells, Hb: hemoglobin, Hct: hematocrit, Plt: platelets, PT: prothrombin, PT-INR: prothrombin time-international normalized ratio, APTT: activated partial thromboplastin time, Fib: fibrinogen, FDP: fibrin degradation products, AT-III: anti-thrombin III, Lac: lactate, TP: total protein, Alb: albumin, T-Bil: total bilirubin, AST: aspartate aminotransferase, ALT: alanine aminotransferase, BUN: blood urea nitrogen, Cre: creatinine, Na: sodium, K: potassium, $\mathrm{Cl}$ : chloride, Glu: glucose, CRP: C reactive protein, PCT: procalcitonin, $\mathrm{NH}_{3}$ : ammonia, HD: hemodialysis

showed cerebral edema (Fig. 1B). Her electroencephalography showed frequent triphasic waves.

She was diagnosed with hyperammonemic encephalopathy, and tracheal intubation was performed. Treatment with branched chain amino acid infusion, continuous hemodiafiltration and intravenous injection of meropenem were also started. Her blood $\mathrm{NH}_{3}$ decreased to $47 \mu \mathrm{g} / \mathrm{d} l$ and her consciousness recovered to a normal state on the third day after admission to the ICU. The tracheal tube was extubated on the fourth day and she left the ICU on the seventh day. Her head computed tomography after recovery of consciousness showed improvement of the cerebral edema (Fig. 1C). Inflammatory response also improved after administration of meropenem instead of ceftriaxone (Fig. 2). Enterococcus species and clostridium difficile toxin non-producing Clostridium difficile were isolated from her stool culture, and Enterococcus faecium was detected from one of the 
aerobic bottles among two sets of blood culture bottles. Enterococcus faecium was considered to be contamination, as it was resistant to meropenem and could not explain her clinical course.

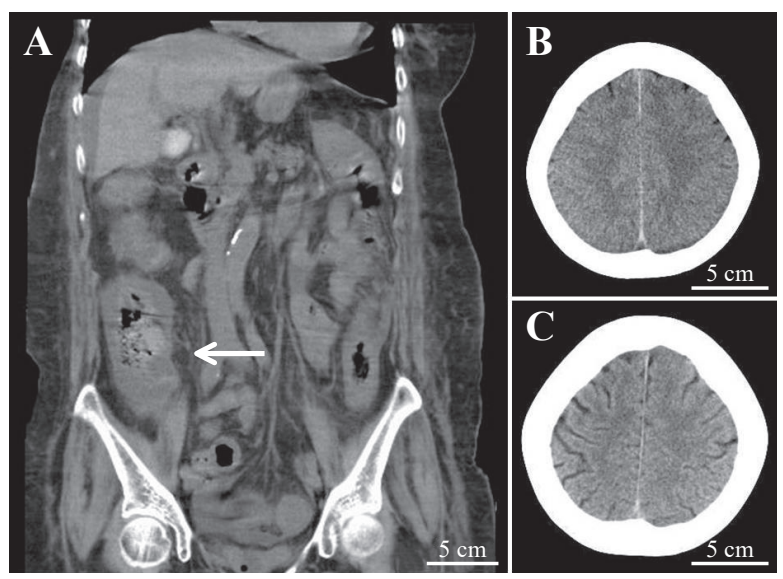

Fig. 1. Computed tomography images. A. A coronal section of abdominopelvic plain computed tomography image shows thickening of the ascending colon (white arrow) and ascites around the liver. B. A head computed tomography image on admission to the ICU shows cerebral edema. C. A head computed tomography image after recovery of consciousness shows improvement of cerebral edema.

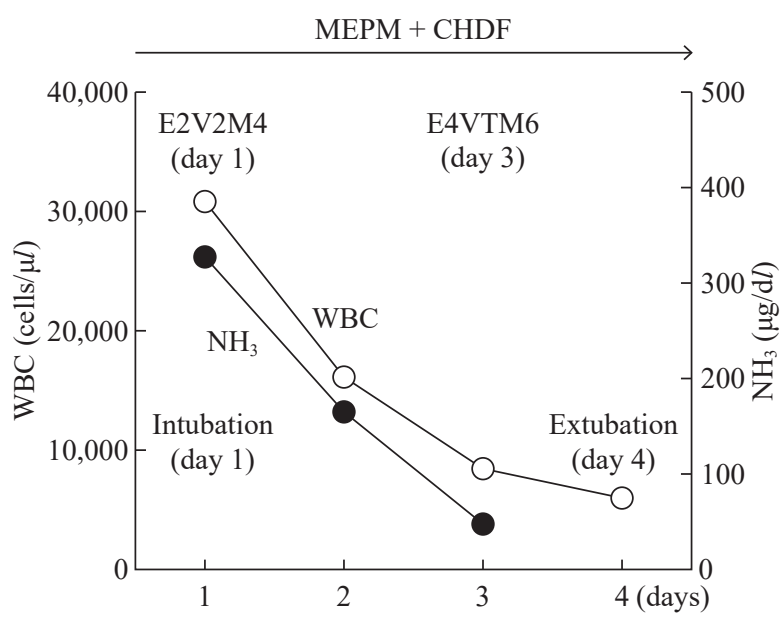

Fig. 2. Clinical course after admission to the ICU. Blood level of $\mathrm{NH}_{3}$ decreased to $47 \mu \mathrm{g} / \mathrm{d} l$ and consciousness was recovered on the third day. $\mathrm{NH}_{3}, \mathrm{O}: \mathrm{WBC}, \mathrm{E} 2 \mathrm{~V} 2 \mathrm{M} 4$ : eye opening 2 verbal response 2 motor response 4, E4VTM6: eye opening 4 verbal response tube motor response 6, MEPM: meropenem, CHDF: continuous hemodiafiltration, WBC: white blood cells.

\section{Discussion}

The cause of the patient's comatose condition was considered to be hyperammonemic encephalopathy in this case, because her blood $\mathrm{NH}_{3}$ as significantly high at 324 $\mu \mathrm{g} / \mathrm{d} l$, her head computed tomography showed cerebral edema, and her consciousness and cerebral edema improved after $\mathrm{NH}_{3}$ decreased to a normal range. Although the mechanism of cerebral edema in hepatic encephalopathy remains to be defined, it is well recognized that $\mathrm{NH}_{3}$ is a major factor in its pathogenesis and that astrocyte swelling is a major component of cerebral edema [6].

There are three main causes of hyperammonemia: 1 . metabolic disorders such as liver dysfunction and portosystemic shunts, 2 . overproduction such as ureaseproducing bacteria infection, and 3.decreased excretion due to renal dysfunction or constipation [7-9]. Her liver function was relatively stable at the prothrombin time-international normalized ratio 1.21, and portal shunts or hepatic atrophy was not clear in CT. There was also no medical history of excessive protein intake or constipation during the clinical course. The influence of urease-producing bacteria and renal dysfunction were considered to be the causes of hyperammonemia in this case, but since renal dysfunction alone rarely causes hyperammonemia, the main cause of hyperammonemia was suspected to be infection with urease-producing bacteria. Hyperammonemia may occur due to the side effects of drugs such as valproic acid $[10,11]$, but she was not medicated with any drugs that could cause hyperammonemia.

Urease is an enzyme that catalyzes hydrolysis urea to ammonia and carbamate, and urease-producing bacteria have been reported to cause hyperammonemia in humans [7, 12]. Reports of hyperammonemia due to urease-producing bacteria such as Klebsiella spp., Proteus spp., Corynebacterium spp. and Staphylococcus spp. are commonly found, but most hyperammonemia are caused by urinary tract infections [1-4]. Besides urinary tract infections, there is a report of hyperammonemia due to empyema caused by anaerobic bacteria [5], but there are no reports of infectious enterocolitis. In cases of urinary tract infections and empyema, consciousness improved as blood $\mathrm{NH}_{3}$ decreased to the normal range after intervention for treatment of infection, such as release of urinary retention, thoracic 
drainage and administration of antibiotics. Neither urinary tract infection nor empyema was observed in this case, and the focus of inflammation was considered to be in the intestinal tract because of frequent diarrhea and edematous changes in the ascending colon.

Most of the blood ammonia of humans is derived from the intestinal tract in healthy condition. Although constipation was not observed in the present case, abdominal CT showed marked edema of the intestinal tract. Increased vascular permeability and inner pressure of the intestinal tract caused by enterocolitis might have affected the blood ammonia concentration. In cases of infectious enterocolitis, it might be possible that urease-producing bacteria abnormally proliferate and decompose urea to $\mathrm{NH}_{3}$ in the intestinal tract, which leads to coma with hyperammonemia. Unlike urinary tract infections and empyema, it is usually difficult to identify accurate pathogenic bacteria in enterocolitis because there are various bacteria in the intestinal tract, which can explain why there have been no reports like this case so far.

Enterococcus species and Clostridium difficile were isolated from the feces, but neither of them are ureaseproducing bacteria. Enterococcus faecium was detected from the blood culture, but, as mentioned above, it was considered to be due to contamination. Colonies of Enterococcus faecium were applied to an urea agar base to confirm the urease productivity [13], but urease productivity was not confirmed.

When identifying pathogenic bacteria in infectious enterocolitis by culture methods, it is often difficult to identify the pathogenic bacteria, as mentioned above. Healthy adult gut microbiota are dominated by Bacteroidetes and Firmicutes but also include smaller proportions of Actinobacteria, Proteobacteria, and Verrucomicrobia [14]. Among these, some Bacteroides, Clostridium, Klebsiella, Proteus and Salmonella have urease productivity. The bacterial flora of the intestinal tract in this case might have been disturbed due to steroids and immunosuppressive therapy. Intravenous ceftriaxone also might have been attributable to the abnormal proliferation of urease-producing anaerobic bacteria in the intestinal tract.

The cause of hyperammonemia was suspected to be urease-producing infection in this case, but it was not clear. We speculate that the bacterial flora in the intestinal tract had been disturbed due to steroids, immunosuppressive therapy and ceftriaxone, and that urease-producing bacteria in the intestinal tract such as Bacteroides, Clostridium, Klebsiella, Proteus and Salmonella proliferated abnormally, developing into infectious enterocolitis with hyperammonemia.

\section{Conclusions}

We reported a case of infectious enterocolitis with hyperammonemia in which the causative bacteria was speculated to be urease-producing bacteria. It is necessary to consider the influence of urease-producing bacteria as a cause of hyperammonemia not only in urinary tract infections but also in infectious enterocolitis.

\section{Conflicts of Interest}

The authors declare no conflicts of interest.

\section{References}

1. De Jonghe B, Janier V, Abderrahim N, Hillion D, Lacherade JC \& Outin H (2002): Urinary tract infection and coma. Lancet 360: 996

2. Tamura N, Shiino Y \& Suzuki K (2015): Two case reports of hyperammonemia with urinary tract infection by urease-producing bacteria. J Jpn Soc Intensive Care Med 22: 33-37 (in Japanese)

3. Samtoy B \& DeBeukelaer MM (1980): Ammonia encephalopathy secondary to urinary tract infection with Proteus mirabilis. Pediatrics 65: 294-297

4. Saito N, Yagi T, Hayashida K, Hara Y, Matsumoto H, Mashiko K \& Yokota H (2012): Hyperammonemic in urinary tract infection with Staphylococcus intermedius: a case report. JJAAM 23: 205-210 (in Japanese)

5. Kuze N, Nishizaka Y, Okamoto K, Wakayama T, Imanaka M, Kubo Y, Oda Y \& Amitani R (2000): Empyema thoracis accompanied by hyperammonemic encephalopathy. Nihon Kokyuki Gakkai Zasshi 38: 117121 (in Japanese)

6. Albrecht J \& Norenberg MD (2006): Glutamine: A Trojan horse in ammonia neurotoxicity. Hepatology 44: 788-794

7. Mora D \& Arioli S (2014): Microbial urease in health and disease. PLoS Pathog 10: e1004472 
8. Plauth M, Roske AE, Romaniuk P, Roth E, Ziebig R \& Lochs H (2000): Post-feeding hyperammonaemia in patients with transjugular intrahepatic portosystemic shunt and liver cirrhosis: role of small intestinal ammonia release and route of nutrient administration. Gut 46: $849-855$

9. Elwir S \& Rahimi RS (2017): Hepatic encephalopathy: an update on the pathophysiology and therapeutic options. Clinical and Translational Hepatology 5: 142151

10. Aires CC, Cruchten AV, Ijlst L, Almeida IT, Duran M, Wanders RJ \& Silva MF (2011): New insights on the mechanisms of valproate-induced hyperammonemia: inhibition of hepatic $\mathrm{N}$-acetylglutamate synthase activity by valproyl-CoA. J Hepatol 55: 426-434
11. Kondo T, Ishida M, Kaneko S et al (1992): Is 2-propyl4-pentenoic acid, a hepatotoxic metabolite of valproate, responsible for valproate-induced hyperammonemia? Epilepsia 33: 550-554

12. Mobley HL, Island MD \& Hausinger RP (1995): Molecular biology of microbial ureases. Microbiol Rev 59: $451-480$

13. Christensen WB (1946): Urea decomposition as a means of differentiating Proteus and paracolon cultures from each other and from Salmonella and Shigella types. J Bacteriol 52: 461-466

14. Eckburg PB, Bik EM, Bernstein CM, Purdom E, Dethlefsen L, Sargent M, Gill SR, Nelson KE \& Relman DA (2005): Diversity of the human intestinal microbial flora. Sciece 308: 1635-1638 
高アンモニア血症を伴った感染性腸炎の1例

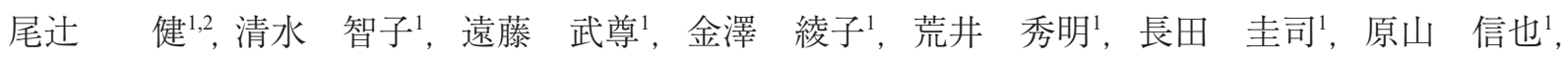

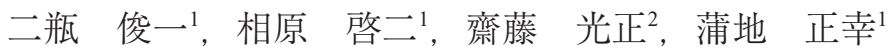

1 産業医科大学病院 集中治療部

2 産業医科大学 医学部 微生物学教室

要旨：ウレアーゼ産生菌のため高アンモニア血症を来した報告は散見されるが, その多くは尿路感染症であ る。今回我々はウレアーゼ産生菌による感染性腸炎のため高アンモニア血症を来したと考えられた症例を経験し た，症例は70歳代女性．近医で顕微鏡的多発血管炎と診断され当院へ紹介となった，ステロイド療法㧍よびリッ キシマブを開始して顕微鏡的多発血管炎は比較的落ち着いていたが, 頻回の下痢および高アンモニア血症 $(324 \mu \mathrm{g} /$ $\mathrm{d} l$ ) を認め, 昏睡状態となった。感染性腸炎抢よび高アンモニア血症に対して, 抗菌薬による加療抢よびアンモニア の解毒療法を開始したところ, 血中アンモニアは $47 \mu \mathrm{g} / \mathrm{d} l$ まで低下し意識は清明となった．高アンモニア血症の原因 としては, 肝機能障害や門脈体循環シャント, 蛋白質過剩摂取, 便秘は認めず, 薬剤性の高アンモニア血症も否定的で あり, ウレアーゼ産生菌によるアンモニア過剩産生が疑われた。本症例で提出した培養結果からはウレアーゼ産生 能をもつ原因菌は特定できなかったが, 培養で同定することが出来なかったウレアーゼ産生菌が, 高アンモニア血症 を引き起こしていた可能性が高いと考えられた，尿路感染症だけでなく, 感染性腸炎に拈いても, 高アンモニア血症 の原因としてウレアーゼ産生菌による影響を考慮する必要がある.

キーワード：高アンモニア血症, ウレアーゼ, 感染性腸炎.

J UOEH(産業医大誌) 39(4)：271 - 276 (2017) 